\title{
Staphylococcal Protein A Is a Key Factor in Neutrophil Extracellular Traps Formation
}

\begin{abstract}
Tamara Hoppenbrouwers ${ }^{1,2 t}$, Andi R. Sultan ${ }^{3 t}$, Tsion E. Abraham ${ }^{4}$, Nicole A. Lemmens-den Toom $^{3}$, Silvie Hansenová Mañásková ${ }^{3}$, Wiggert A. van Cappellen ${ }^{4}$, Adriaan B. Houtsmuller ${ }^{4}$, Willem J. B. van Wamel ${ }^{3}$, Moniek P. M. de Maat ${ }^{2}$ and Johan W. van Neck ${ }^{\text {* }}$
\end{abstract}

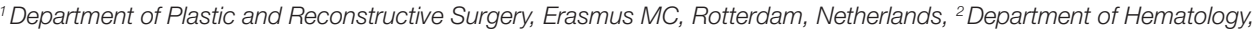
Erasmus MC, Rotterdam, Netherlands, ${ }^{3}$ Department of Medical Microbiology and Infectious Diseases, Erasmus MC, Rotterdam, Netherlands, ${ }^{4}$ Erasmus Optical Imaging Center, Department of Pathology, Erasmus MC, Rotterdam, Netherlands
\end{abstract}

Staphylococcus aureus are strong inducers of neutrophil extracellular traps (NETs), a defense mechanism of neutrophils against pathogens. Our aim was to explore the role of Protein A in S. aureus-induced NETosis. We determined the Protein A production of four different $S$. aureus strains and found a direct relationship between the degree of NETosis induction and Protein A production: strains producing higher concentrations of Protein A evoke significantly more NETs. A S. aureus strain in which Protein A as well as a second binding protein for immunoglobulins (Sbi) have been knocked-out $(\triangle S p A \Delta S b i)$ induced significantly less NETosis than the wild-type strain. NETosis induction by this knockout strain can be rescued by the addition of purified Protein A. Dead S. aureus did not induce NETosis. In conclusion, Protein A is a determinant for NETosis induction by S. aureus.

Keywords: neutrophil extracellular traps, NETs, S. aureus, Staphylococcus aureus, Protein A, SpA

\section{INTRODUCTION}

Upon encountering bacteria, neutrophils can form neutrophil extracellular traps (NETs) as part of their antimicrobial defense mechanism. During NETosis, neutrophils excrete their DNA into the extracellular space, along with histones and other antimicrobial factors. These NETs trap bacteria and thereby limit bacterial spreading $(1,2)$. NETs have been shown to play an important role in contributing to several pathological conditions, such as chronic wounds (3), thrombosis (4-6), and sepsis (7-9).

The bacterial inducing capacity of NETosis is different between bacterial species (10). A very potent inducer of NETosis is Staphylococcus aureus $(11,12)$. S. aureus is a Gram-positive bacterium that can cause many different infections and, particularly when dealing with methicillin-resistant S. aureus, can cause critical problems in hospitals. S. aureus possesses multiple evasion strategies against the human immune system, such as the production of immune-modulators (13-17) and the secretion of nucleases, which enables them to escape NETs (16).

Staphylococcus aureus also can evade phagocytosing neutrophils by blocking neutrophil rolling on activated endothelial cells and by targeting both antibodies and opsonins, necessary for pathogen recognition by neutrophils (18). One of the main bacterial proteins involved in phagocytosis evasion is Protein A. Staphylococcal Protein A (SpA) is a $42-\mathrm{kDa}$ large protein which is covalently linked to the staphylococcal surface and can be secreted into the extra-bacterial environment $(17,19,20)$.

Staphylococcal Protein A is known to be able to manipulate or to avoid early host adaptive immune responses. It can bind to the Fcy domain of IgG and, therefore, inhibit opsonization that precedes phagocytosis $(17,19-21)$. Furthermore, it can induce apoptosis in B-cells by binding to the Fab 
regions of the B-cell receptor and act as a B-cell superartigen (22). However, little is known about its direct effect on innate immune cells, particularly neutrophils. Since neutrophils are one of the earliest effector host immune cell against $S$. aureus invasion and because of their ability to form NETs, we were interested to study whether Protein A is also involved in NETosis. To achieve this, we determined the Protein A production in different $S$. aureus strains and its relationship with NETosis inducing capacity. Next, we obtained more insight in the role of Protein A in NETosis by studying the rescue of NETosis with Protein A in a $S$. aureus Protein A knockout strain.

\section{MATERIALS AND METHODS}

\section{Bacterial Strains}

Bacterial strains used in this study are listed in Table 1. Strains were obtained from the bacterial collection of Department of Medical Microbiology and Infectious Diseases, Erasmus MC Rotterdam.

\section{Bacterial Growth Condition}

All strains were cultured on Trypticase ${ }^{\mathrm{TM}}$ Soy Agar (TSA) (Becton Dickinson, Breda, The Netherlands) with 5\% sheep blood overnight at $37^{\circ} \mathrm{C}$. Protein $\mathrm{A}$ and the second binding protein for immunoglobulins ( $S b i)$ double knockout Newman strain $(\Delta S p A$ $\Delta S b i$ ) was cultured on TSA containing $5 \mu \mathrm{g} / \mathrm{ml}$ gentamycin and $5 \mu \mathrm{g} / \mathrm{ml}$ tetracycline to maintain its knockout status. After an overnight incubation at $37^{\circ} \mathrm{C}$, bacteria were suspended in $\mathrm{NaCl}$ $0.9 \%$ solution ( $\mathrm{OD} 0.5$ at $\mathrm{OD}_{600 \mathrm{~nm}}$ ), and $200 \mu \mathrm{l}$ was added to a sterile Erlenmeyer flask containing $100 \mathrm{ml}$ Iscove's Modified Dulbecco's Medium (IMDM) (Gibco, Bleiswijk, The Netherlands).

The flask was then incubated for $24 \mathrm{~h}$ at $37^{\circ} \mathrm{C}$ at $150 \mathrm{rpm}$. The next day, based on $\mathrm{OD}_{600 \mathrm{~nm}}$ measurements, the individual strains were concentrated to reach a final concentration of $2 \times 10^{10} \mathrm{bac}-$ teria/ml. Heat killed bacteria were generated by incubating the bacteria at $96^{\circ} \mathrm{C}$ for $10 \mathrm{~min}$. Bacteria were then harvested and transferred to new IMDM medium. To control for the effectiveness of the heat treatment, the heat-killed bacteria were stained with propidium iodide (PI, diluted 1:400, Sigma Aldrich, Zwijndrecht, The Netherlands) and a sample was cultured to check for growth by plating.

\section{Secreted Protein A Measurement}

The concentrations of released Protein A by S. aureus strains were measured using a sandwich ELISA type assay specific for Protein

TABLE 1 | Overview of the Staphylococcus aureus strains used in this study.

\begin{tabular}{lcl}
\hline Strain & Genetic background & Description \\
\hline Newman & ST8 & Wild type, laboratory strain \\
USA300 & ST8 & Clinical strain \\
M116 & ST238, ST8 & Clinical strain \\
RN6390 & ST8 & Laboratory strain, derivative of \\
& & $8325-4$ \\
Newman $\Delta$ SpA & ST8 & Laboratory strain, derivate from \\
$\Delta$ Sbi & & Newman strain
\end{tabular}

A (Enzo, Bruxelles, Belgium) according to the manufacturer's protocol. The detection range of the kit was 15.6-1,000 pg Protein A/ml. S. aureus strains Newman, USA300, RN6390, M116, and Newman $\Delta S p A \Delta S b i$ were cultured as described above and after overnight culturing, $20 \mu \mathrm{l}$ of the supernatant was collected, centrifuged at 4,000 $g$, and then filtered. Supernatant from Newman $\triangle S p A \Delta S b i$ bacteria was included as a negative control. The optical density at $450 \mathrm{~nm}$ was measured using a Biotek plate reader (Biotek) with Gen5 software and used to calculate the protein A concentration.

\section{FACS Analysis of Surface Associated Protein A}

Four milliliters of IMDM were inoculated with an overnight culture of $S$. aureus (Newman, USA300, RN6390, and M116) to obtain $\mathrm{OD}_{600 \mathrm{~nm}}$ of 0.05 . The individual cultures were incubated for $24 \mathrm{~h}$ at $37^{\circ} \mathrm{C}$ with continuous shaking at $230 \mathrm{rpm}$. The $\mathrm{OD}_{600 \mathrm{~nm}}$ of the bacteria culture was normalized to 0.300 , and the bacteria were washed 3 times with PBS, followed by centrifugation for $5 \mathrm{~min}$ at $4,000 \mathrm{~g}$. The individual bacterial pellets were suspended in $100 \mu \mathrm{l} \mathrm{PBS}$. Ten microliters of each bacterial suspension were mixed with either $10 \mu \mathrm{l}$ of 1:50 dilution of anti-protein A IgY-FITC (FITC-labeled Chicken anti-Protein A), (Gallus Immunotech Inc., Fergus, Canada) or with $10 \mu \mathrm{l}$ PBS, used as negative control, in an U shape 96-well microplate (Greiner BioOne, Oberösterreich, Germany). The plate was then incubated at $10^{\circ} \mathrm{C}$ for $45 \mathrm{~min}$ at $800 \mathrm{rpm}$ in the dark. After washing 3 times with $200 \mu \mathrm{l}$ PBS, bacteria were centrifuged for $5 \mathrm{~min}$ at 3,500 $\mathrm{g}$. Bacteria were suspended in $50 \mu \mathrm{l}$ of PBS and their fluorescence (emission 488-522 nm) was quantified with Accuri C6 Flow Cytometer and analyzed using Accuri C6 Software (version 1.0.264.21) (both BD Bioscience, Breda, The Netherlands). Values are expressed in mean fluorescence intensity (MFI).

\section{Neutrophil Isolation}

Neutrophils were isolated as described previously (23), under endotoxin-free conditions. Briefly, medium Lymphoprep ${ }^{\mathrm{TM}}$ (Stemcell Technologies) was used to isolate neutrophils from blood derived from healthy donors within the age range of 25-50. Donors did not use any medication (e.g., anti-inflammatory drugs) that could influence study results. Red blood cells were lysed using Erythrolysis buffer $\left(155 \mathrm{mM} \mathrm{NH}_{4} \mathrm{Cl}, 10 \mathrm{mM} \mathrm{KHCO}_{3}\right.$, $1 \mathrm{mM}$ EDTA, pH 7.4) and then neutrophils were washed two times with HEPES buffer. A final neutrophil concentration of $2 \times 10^{7}$ cells $/ \mathrm{ml}$ was used. All experiments were approved by the Medical Ethics Committee of the Erasmus MC. Each experiment was performed with neutrophils derived from a different donor.

\section{NETosis Induction and Imaging}

Neutrophils were stained for DNA with Hoechst 34580 (diluted 1:10,000, Life Technologies) and for extracellular DNA with PI (diluted 1:400, Sigma Aldrich) in $500 \mu \mathrm{l}$ DMEM culture medium (Biowhittaker, Lonza). The cells were allowed to attach to gelatincoated coverslips at $37^{\circ} \mathrm{C}$ for at least $1 \mathrm{~h}$.

To induce NETosis, $500 \mu \mathrm{l} 2 \times 10^{10}$ bacteria/ml were added to $500 \mu \mathrm{l} 2 \times 10^{7}$ neutrophils $/ \mathrm{ml}$ in a Attofluor Cell Chamber 
(Thermo Fisher Scientific, Bleiswijk, The Netherlands). The chamber was sealed, and the neutrophils were continuously imaged with a confocal microscope (Leica SP5 AOBS) with a $40 \times$ magnification and numerical aperture (n.a.) of 1.25. Hoechst and PI were excited by $405 \mathrm{~nm}$ (emission BP 450-550 nm) and $561 \mathrm{~nm}$ (emission 570-620 nm) lasers, respectively. NETs were visible as PI positive elongated structures and were quantified (see NETs Quantification).

In order to study the effect of Protein A on NETosis induction by $S$. aureus Newman $\Delta S p A \Delta S b i$ strain, $100 \mu$ l of either $0.01,0.1$, or $1 \mathrm{mg} / \mathrm{ml}$ of purified Protein A (Sigma Aldrich, Zwijndrecht, The Netherlands) was added to the Newman $\Delta S p A \Delta S b i$ strain prior to co-incubation with neutrophils (final concentration range $0.9-90 \mu \mathrm{g} / \mathrm{ml}$ Protein A).

\section{NETs Quantification}

$z$-Stack images were taken from randomly distributed fields of view within the cell chamber every 3-5 min, in a time frame of 5-40 min. Every image had the same $X, Y$, and $Z$ dimensions. In each image, NETs were manually traced in every $z$-stack by using ImageJ (Version 1.49, National Institutes of Health, USA). The total volume (cubic micrometer) of NETs was calculated from 10 to 15 images per strain. The average percentage of
NETs coverage was then calculated: total volume of NETs/total volume.

\section{Statistical Analyses}

Data are presented as mean \pm SEM. A statistical unpaired, twotailed $t$-test with Statistical Package for the Social Sciences (SPSS IBM, version 21) was used to analyze differences between groups. Results were considered significant when $p<0.05$.

\section{RESULTS}

The secretion of Protein A in the supernatant of the overnight grown $S$. aureus USA300 (ST8) was significantly higher than that of M116 and RN6390 $(0.31 \pm 0.03 \mu \mathrm{g} / \mathrm{ml}$ USA300 vs $0.04 \pm 0.01 \mu \mathrm{g} / \mathrm{ml} \mathrm{M116}, p<0.001$ and $0.31 \pm 0.03 \mu \mathrm{g} / \mathrm{ml}$ USA300 vs $0.07 \pm 0.02 \mu \mathrm{g} / \mathrm{ml}$ RN6390, $p<0.001)$. S. aureus Newman secreted significantly more Protein A than M116 $(0.26 \pm 0.09 \mu \mathrm{g} / \mathrm{ml}$

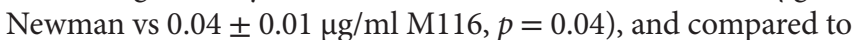
$S$. aureus RN6390, a trend could be observed $(0.26 \pm 0.09 \mu \mathrm{g} / \mathrm{ml}$ Newman vs $0.07 \pm 0.02 \mu \mathrm{g} / \mathrm{ml}, p=0.06$ ) (Figure 1A). No Protein A was measured in the Protein A knockout Newman $\Delta S p A \Delta S b i$.

The amount of Protein A associated to the bacterial surface was higher in Newman and USA300 (3,703 \pm 404 MFI and
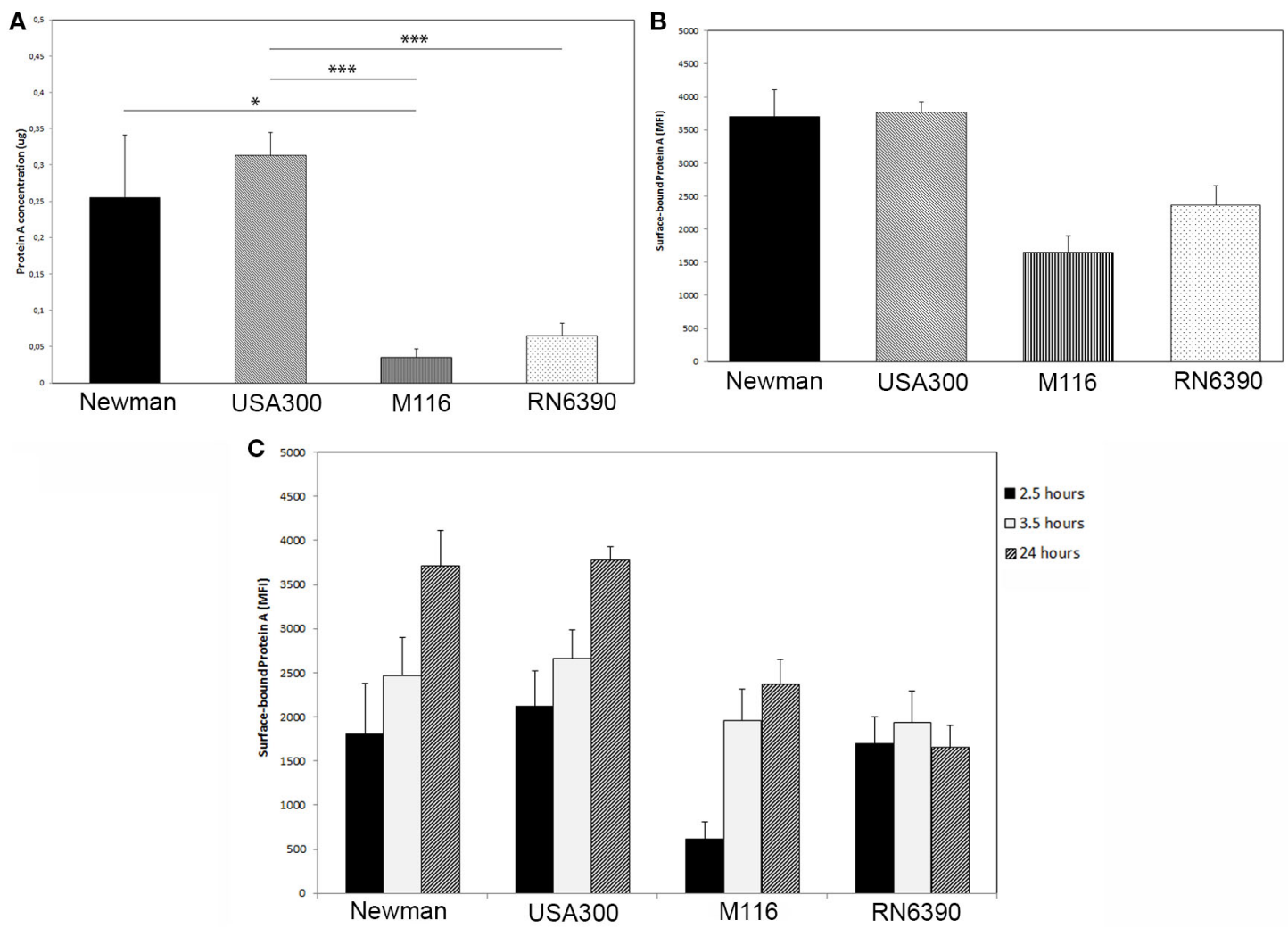

FIGURE 1 | Protein A production by Staphylococcus aureus. (A) Protein A secretion is higher in S. aureus strains Newman and USA300 compared to S. aureus strains M116 and RN6390, as determined by an ELISA assay $(n=5)$. (B) More Protein A is bound to the surface of $S$. aureus strains Newman and USA300 compared to S. aureus strains M116 and RN6390, as determined by FACS $(n=3)$. (C) Amount of Protein A bound to the surface of $S$. aureus measured on 2.5, 3.5 , and $24 \mathrm{~h}$ as determined by FACS. Except for strain RN6390, the amount of surface bound Protein A is increasing over time $(n=3$, neutrophils derived from three individual donors). 
3,767 \pm 163 MFI, respectively) compared to M116 and RN6390 $(2,336 \pm 288 \mathrm{MFI}$ and $1,649 \pm 254 \mathrm{MFI}$, respectively) (Figure 1B). In literature, it was described that Protein $\mathrm{A}$ is in particular expressed in classical bacterial growth media during the exponential growth phase. To determine if this is the case in IMDM, we as well made a growth curve and determined at three time points the amount of surface associated Protein A. Interestingly, the level of the surface associated Protein A during stationary phase (2.5 and $3.5 \mathrm{~h}$ ) is higher compared to its exponential phase (24 h, Figure 1C), except for strain RN6390.

When we tested these $S$. aureus strains to see whether the amount of Protein A plays a role in NETosis, we observed a positive correlation between Protein A levels and NETosis. High Protein A-producing strains Newman and USA300 induced significantly more NETosis (Newman $10.7 \pm 1.9 \%$ and USA300 $13.5 \pm 3.8 \%$ of the total volume) compared to the low Protein A-producing strains M116 $(0.7 \pm 0.2 \%, p<0.001$ and $p=0.003$, respectively $)$ and RN6390 (3.4 $\pm 1.4 \%, p=0.005$ and $p=0.02$, respectively) (Figure 2). Corresponding NETs volumes are 3,750 $\pm 675 \mu \mathrm{m}^{3}$ (Newman), 4,738 $\pm 1347 \mu \mathrm{m}^{3}$ (USA300), $245 \pm 72 \mu \mathrm{m}^{3}$ (M116), and 1,208 $\pm 482 \mu \mathrm{m}^{3}$ (RN6390). NETosis in all strains started within $5 \mathrm{~min}$ and within $40 \mathrm{~min}$ all neutrophils had formed NETs.

To further determine the contribution of Protein A to NETosis induction, we used a $S p A$ Sbi double knockout strain of $S$. aureus Newman $(\triangle S p A \Delta S b i)$ to induce NETosis. Only very modest NETosis was observed $(2.3 \pm 0.9 \%)$, which was significantly lower than of the WT Newman strain $(p<0.001)$. We could recover NETosis by the knockout strain by adding purified Protein A. Addition of $0.9,9$, or $90 \mu \mathrm{g} / \mathrm{ml}$ of purified Protein A to the knockout strain, prior to NETosis induction, rescued NETosis induction $(8.1 \pm 1.9 \%, p=0.01 ; 7.4 \pm 1.2 \%, p=0.005$ $7.2 \pm 1.7 \%, p=0.02$, respectively) (Figure 3) to comparable levels that were observed for WT Newman strain $(p=0.36, p=0.26$, and $p=0.19$, respectively).
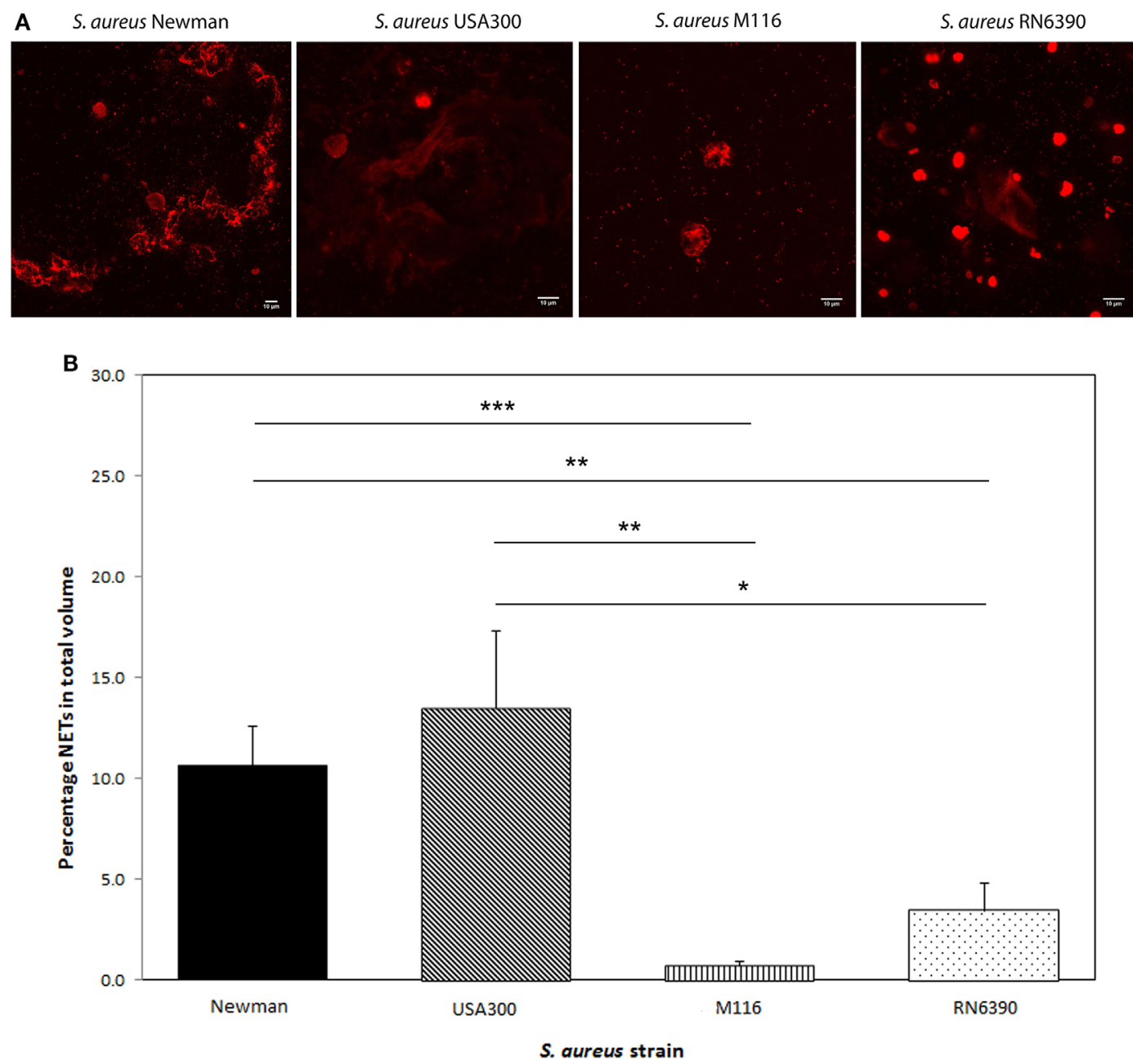

FIGURE 2 | Neutrophil extracellular traps (NETs) induction by different Staphylococcus aureus strains Newman, USA300, M116, and RN6390. (A) In vitro NETs formation as indicated by propidium iodide (red). (B) Strains Newman and USA300 induce significantly more NETs than M116 and RN6390, as indicated by percentage of NETs coverage in the total volume. Results of three separate experiments, neutrophils were derived from three individual donors $\left({ }^{*} p<0.05\right.$; $\left.{ }^{* *} p<0.01 ;{ }^{* * *} p<0.001\right)$. 


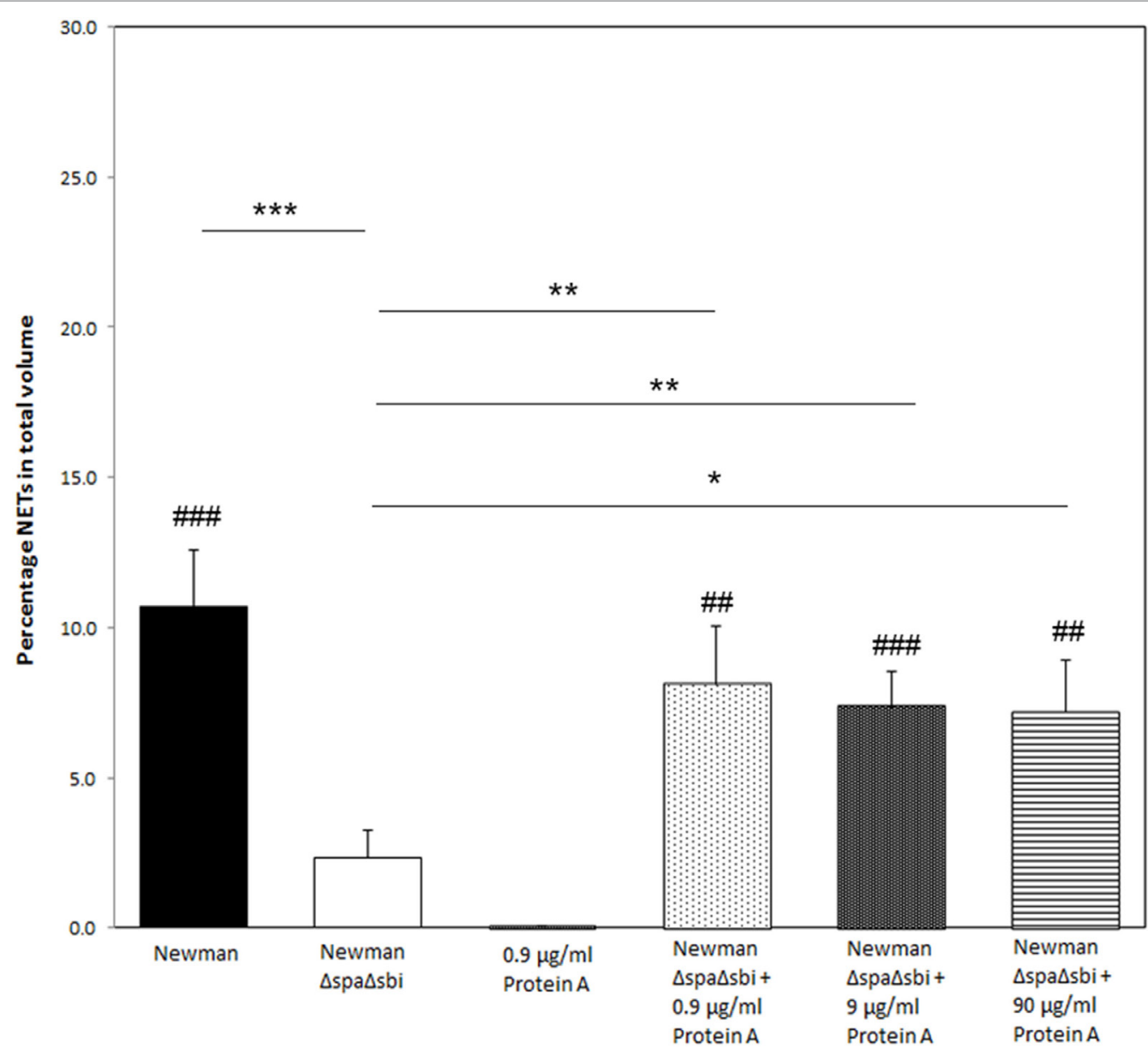

FIGURE 3 | Reversed effect of significantly reduced NETosis by Staphylococcus aureus knockout strain after the addition of purified Protein A. Except for S. aureus Newman $\triangle S p A \Delta S b i$, all conditions induce more NETosis than Protein A only. Results of three separate experiments, neutrophils were derived from three individual donors. * indicates significant difference from S. aureus Newman $\Delta S p A \Delta S b i$. \# indicates significant difference when compared to neutrophils stimulated with $0.9 \mu \mathrm{g} / \mathrm{ml}$ Protein $\mathrm{A}\left({ }^{\star} / \# p<0.05 ;{ }^{\star \star} / \# \# p<0.01 ;{ }^{* \star \star} / \# \# \#<0.001\right)$.

Additionally, we also were able to rescue NETosis formation to the level induced by WT Newman when Protein A was added to the modestly NETosis inducing strain M116 $(0.7 \pm 0.2 \%$ in M116 vs $9.1 \pm 2.0 \%$ in M116 plus Protein A, $p<0.001)$, giving it the same NETosis induction rate compared to WT Newman ( $p=0.63$, Figure 4).

No NETosis was observed when $0.9,9$, or $90 \mu \mathrm{g} / \mathrm{ml}$ of purified Protein A was added to the neutrophils without bacteria $(0.0 \pm 0.0$, Figure 3$)$. To explore the effect of bacterial viability on NETosis induction, 0.9 and $9 \mu \mathrm{g} / \mathrm{ml}$ Protein A were added to dead bacteria (WT Newman). No NETosis was observed (Figure 4) which indicates that living bacteria are needed in order to induce NETosis. We observed that dead bacteria were phagocytosed by neutrophils, however, when $0.9-90 \mu \mathrm{g} / \mathrm{ml}$ Protein A was added, bacteria were not cleared by the neutrophils (Figure 5).

\section{DISCUSSION}

In this study, we demonstrated that Protein A secretion is positively correlated to NETosis induction by $S$. aureus. Previously, it has been described that different bacterial species induce different NETosis responses $(10,12,23)$. We showed that between different $S$. aureus strains, differences in NETosis response are seen, which is correlated to the amount of Protein A present. Furthermore, NETosis induction by S. aureus with little to no Protein A present can be rescued by adding Protein A.

In our study, the bacterial cell wall-associated protein A level is higher during the stationary phase than during the exponential phase. In a previous study by Gao et al., using trypticase soy broth (TSB) medium, the spa gene, that encodes Protein A in S. aureus, is upregulated in the exponential growth phase of the bacteria and the expression could be regulated via various factors (24). In our experiments, the use of IMDM over TSB is preferred, since we work with neutrophils and the composition of culture media for mammalian cells, such as IMDM, is more closely resembling the composition of human conditions. S. aureus behaves differently in IMDM than when cultured in TSB medium (25), which is an interesting observation.

Protein A is one of the important virulence factors that S. aureus uses to evade the immune system. By Protein A binding 


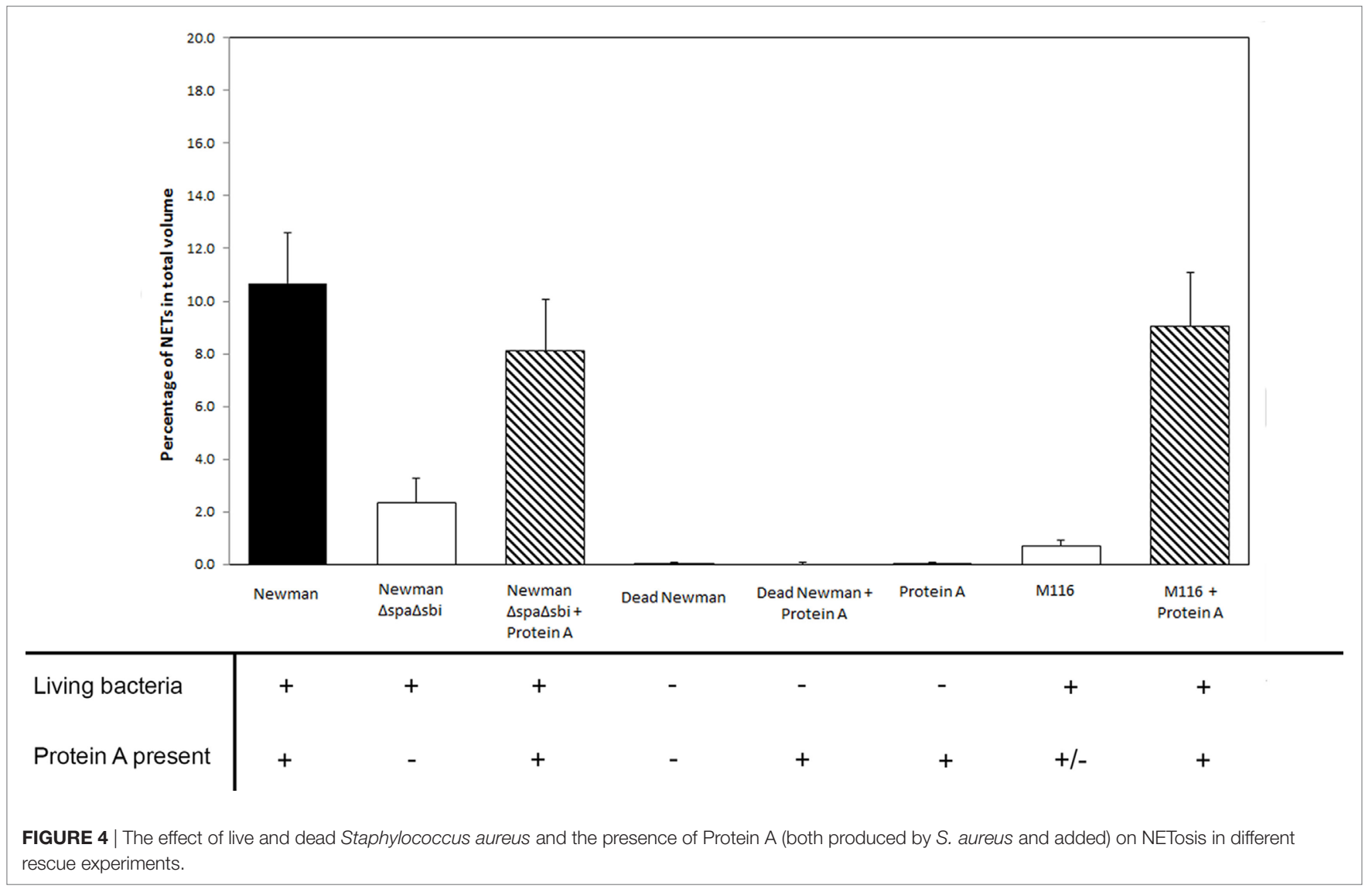

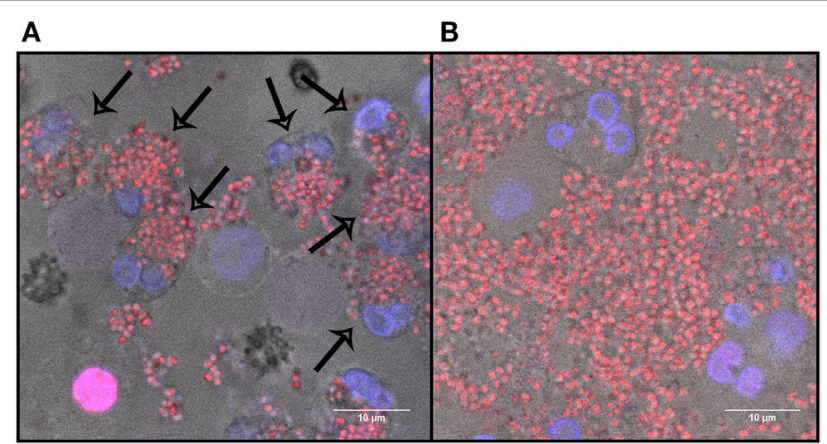

FIGURE 5 | The effect of Protein A on dead bacteria in the presence of neutrophils after 40 min of incubation. (A) Dead Staphylococcus aureus Newman incubated with neutrophils. Arrows indicate phagocytosis. (B) Dead S. aureus Newman incubated with $0.9 \mu \mathrm{g} / \mathrm{ml}$ Protein A and neutrophils. Blue, DNA; red, dead bacteria.

to the $\mathrm{Fc} \gamma$ region of immunoglobulin IgG, bacteria can avoid being opsonized and phagocytosed by neutrophils and other immune cells, as it inhibits binding to the neutrophils Fc receptor (26). In previous experiments, we already reported that dead bacteria are phagocytosed by neutrophils and do not induce NETosis (23). Also, in line with previous experiments (23), no spontaneous NETs were formed within $1 \mathrm{~h}$ of induction, as we showed that
$<1 \%$ of NETs were formed when either dead bacteria or Protein A alone was added to the neutrophils. We now observed that phagocytosis was inhibited when Protein A was added to dead bacteria, although in our experiment, to our knowledge, no IgG was present. Protein A has also been described to bind to the TNFR1 of immune cells, causing production of pro-inflammatory cytokines, such as IL- 6 and TNF- $\alpha$ (27). Both of these cytokines have been described as inducers of NETosis $(28,29)$. In addition, Protein A binding to TNFR1 can cause inhibition of proliferation, mineralization, apoptosis, and activation in osteoclasts, indicating that also in neutrophils, binding to TNFR may activate NETosis. Also, Protein A can activate NADHP oxidase (30), on which NETosis depends (31). However, in our experiments no NETosis was observed when Protein A was added to the neutrophils without bacteria, indicating that another stimulus, for example a different cofactor secreted by living $S$. aureus, is needed in addition to Protein A.

The observations in our study that Protein A is both a determinant of NETs formation and can inhibit phagocytosis without IgG are interesting additions to previous studies, where living $S$. aureus bacteria were reported to degrade the NETs $(16,32)$. These studies speculated that the ability of NETosis induction by bacteria might be a function of bacteria to kill human neutrophils, due to the high survival of bacteria that were able to escape the NETs. Our findings contribute to this hypothesis and suggest that $S$. aureus is not only able to evade phagocytosis by 
secreting Protein A, but also to eliminate the neutrophils by evoking NETosis, from which they can escape by producing nucleases.

In this study, we used the double knockout strain $S$. aureus Newman for SpA and Sbi. The NETosis inducing capacity of this strain also might have been affected by Sbi. Sbi has a similar function and structure as Protein A, and it can interact with complement protein $\mathrm{C} 3$, thereby inhibiting opsonization and, therefore, phagocytosis $(32,33)$. However, in our experiments, we were able to fully rescue NETosis induction by only adding purified Protein A, indicating that Protein A is the important determinant of NETosis in this experimental setting.

In chronic wound infections such as osteomyelitis and ulcers, $S$. aureus is one of the most frequently isolated bacteria $(3,34)$. Also in other diseases where $S$. aureus infection plays a major role, such as sepsis (7) and COPD (35-38), more NETs have been associated with a higher severity of the disease. By understanding more about direct interaction between the human immune

\section{REFERENCES}

1. Branzk N, Papayannopoulos V. Molecular mechanisms regulating NETosis in infection and disease. Semin Immunopathol (2013) 35:513-30. doi:10.1007/ s00281-013-0384-6

2. Brinkmann V, Reichard U, Goosmann C, Fauler B, Uhlemann Y, Weiss DS, et al. Neutrophil extracellular traps kill bacteria. Science (2004) 303:1532-5. doi:10.1126/science. 1092385

3. van Wamel WJ. Staphylococcus aureus infections, some second thoughts. Curr Opin Infect Dis (2017) 30(3):303-8. doi:10.1097/QCO.0000000000000366

4. Fuchs TA, Brill A, Duerschmied D, Schatzberg D, Monestier M, Myers DD Jr, et al. Extracellular DNA traps promote thrombosis. Proc Natl Acad Sci U S A (2010) 107:15880-5. doi:10.1073/pnas.1005743107

5. Varju I, Longstaff C, Szabo L, Farkas AZ, Varga-Szabo VJ, Tanka-Salamon A, et al. DNA, histones and neutrophil extracellular traps exert anti-fibrinolytic effects in a plasma environment. Thromb Haemost (2015) 113:1289-98. doi:10.1160/TH14-08-0669

6. von Bruhl ML, Stark K, Steinhart A, Chandraratne S, Konrad I, Lorenz M, et al. Monocytes, neutrophils, and platelets cooperate to initiate and propagate venous thrombosis in mice in vivo. J Exp Med (2012) 209:819-35. doi:10.1084/ jem.20112322

7. Camicia G, Pozner R, de Larranaga G. Neutrophil extracellular traps in sepsis. Shock (2014) 42:286-94. doi:10.1097/SHK.0000000000000221

8. Clark SR, Ma AC, Tavener SA, McDonald B, Goodarzi Z, Kelly MM, et al. Platelet TLR4 activates neutrophil extracellular traps to ensnare bacteria in septic blood. Nat Med (2007) 13:463-9. doi:10.1038/nm1565

9. Meng W, Paunel-Gorgulu A, Flohe S, Hoffmann A, Witte I, MacKenzie C, et al. Depletion of neutrophil extracellular traps in vivo results in hypersusceptibility to polymicrobial sepsis in mice. Crit Care (2012) 16:R137. doi:10.1186/ cc11442

10. Pilsczek FH, Salina D, Poon KK, Fahey C, Yipp BG, Sibley CD, et al. A novel mechanism of rapid nuclear neutrophil extracellular trap formation in response to Staphylococcus aureus. JImmunol (2010) 185:7413-25. doi:10.4049/ jimmunol.1000675

11. Yipp BG, Petri B, Salina D, Jenne CN, Scott BN, Zbytnuik LD, et al. Infectioninduced NETosis is a dynamic process involving neutrophil multitasking in vivo. Nat Med (2012) 18:1386-93. doi:10.1038/nm.2847

12. Parker H, Dragunow M, Hampton MB, Kettle AJ, Winterbourn CC. Requirements for NADPH oxidase and myeloperoxidase in neutrophil extracellular trap formation differ depending on the stimulus. J Leukoc Biol (2012) 92:841-9. doi:10.1189/jlb.1211601

13. Rooijakkers SH, Ruyken M, Roos A, Daha MR, Presanis JS, Sim RB, et al. Immune evasion by a staphylococcal complement inhibitor that acts on C3 convertases. Nat Immunol (2005) 6:920-7. doi:10.1038/ni1235

14. Higgins J, Loughman A, van Kessel KP, van Strijp JA, Foster TJ. Clumping factor A of Staphylococcus aureus inhibits phagocytosis by human system, in this case neutrophils, and S. aureus, we find more ways to efficiently target the bacteria by interfering with the bacterial products that influence and inhibit our immune system. In conclusion, the amount of Protein A present is an important determinant of NETosis induction by S. aureus, and NETosis inducing capacities of strains with little to no Protein A present can be enhanced by addition of commercial Protein A.

\section{AUTHOR CONTRIBUTIONS}

All authors contributed to the experimental design. Experiments were performed by TH, AS, TA, NT, and SM. Data were processed by TH, AS, TA, and WC. All authors contributed to data interpretation. Figures were generated by $\mathrm{TH}$ and were interpreted by all authors. Statistical analyses were performed by TH and AS. The manuscript was written by TH and AS and revised by all authors.

polymorphonuclear leucocytes. FEMS Microbiol Lett (2006) 258:290-6. doi:10.1111/j.1574-6968.2006.00229.x

15. Agniswamy J, Lei B, Musser JM, Sun PD. Insight of host immune evasion mediated by two variants of group a Streptococcus mac protein. J Biol Chem (2004) 279:52789-96. doi:10.1074/jbc.M410698200

16. Thammavongsa V, Missiakas DM, Schneewind O. Staphylococcus aureus degrades neutrophil extracellular traps to promote immune cell death. Science (2013) 342:863-6. doi:10.1126/science. 1242255

17. Becker S, Frankel MB, Schneewind O, Missiakas D. Release of protein A from the cell wall of Staphylococcus aureus. Proc Natl Acad Sci U S A (2014) 111:1574-9. doi:10.1073/pnas.1317181111

18. Foster TJ. Colonization and infection of the human host by staphylococci: adhesion, survival and immune evasion. Vet Dermatol (2009) 20:456-70 doi:10.1111/j.1365-3164.2009.00825.x

19. Dossett JH, Kronvall G, Williams RC Jr, Quie PG. Antiphagocytic effects of staphylococfcal protein A. J Immunol (1969) 103:1405-10.

20. O'Halloran DP, Wynne K, Geoghegan JA. Protein A is released into the Staphylococcus aureus culture supernatant with an unprocessed sorting signal. Infect Immun (2015) 83:1598-609. doi:10.1128/IAI.03122-14

21. Peterson PK, Verhoef J, Sabath LD, Quie PG. Effect of protein A on staphylococcal opsonization. Infect Immun (1977) 15:760-4.

22. Goodyear CS, Silverman GJ. Death by a B cell superantigen: In vivo VH-targeted apoptotic supraclonal B cell deletion by a Staphylococcal toxin. J Exp Med (2003) 197:1125-39. doi:10.1084/jem.20020552

23. Hoppenbrouwers T, Autar ASA, Sultan AR, Abraham TE, van Cappellen WA, Houtsmuller $\mathrm{AB}$, et al. In vitro induction of NETosis: comprehensive live imaging comparison and systematic review. PLoS One (2017) 12(5):e0176472. doi:10.1371/journal.pone.0176472

24. Gao J, Stewart GC. Regulatory elements of the Staphylococcus aureus protein A (Spa) promoter. J Bacteriol (2004) 186:3738-48. doi:10.1128/ JB.186.12.3738-3748.2004

25. Zapotoczna M, McCarthy H, Rudkin JK, O’Gara JP, O’Neill E. An Essential Role for Coagulase in Staphylococcus aureus biofilm development reveals new therapeutic possibilities for device-related infections. J Infect Dis (2015) 212:1883-93. doi:10.1093/infdis/jiv319

26. Falugi F, Kim HK, Missiakas DM, Schneewind O. Role of protein A in the evasion of host adaptive immune responses by Staphylococcus aureus. MBio (2013) 4:e575-513. doi:10.1128/mBio.00575-13

27. Gonzalez CD, Ledo C, Giai C, Garofalo A, Gomez MI. The Sbi protein contributes to Staphylococcus aureus inflammatory response during systemic infection. PLoS One (2015) 10:e131879. doi:10.1371/journal.pone. 0131879

28. Joshi MB, Lad A, Bharath Prasad AS, Balakrishnan A, Ramachandra L, Satyamoorthy K. High glucose modulates IL-6 mediated immune homeostasis through impeding neutrophil extracellular trap formation. FEBS Lett (2013) 587:2241-6. doi:10.1016/j.febslet.2013.05.053 
29. Gupta AK, Joshi MB, Philippova M, Erne P, Hasler P, Hahn S, et al. Activated endothelial cells induce neutrophil extracellular traps and are susceptible to NETosis-mediated cell death. FEBS Lett (2010) 584:3193-7. doi:10.1016/j. febslet.2010.06.006

30. Mishra A, Dwivedi PD, Verma AS, Ray PK. Protein-A activates membrane bound multicomponent enzyme complex, NADPH oxidase in human neutrophils. Immunopharmacol Immunotoxicol (1999) 21:683-94. doi:10.3109/ 08923979909007134

31. Fuchs TA, Abed U, Goosmann C, Hurwitz R, Schulze I, Wahn V, et al. Novel cell death program leads to neutrophil extracellular traps. J Cell Biol (2007) 176:231-41. doi:10.1083/jcb.200606027

32. Berends ET, Horswill AR, Haste NM, Monestier M, Nizet V, von KockritzBlickwede M. Nuclease expression by Staphylococcus aureus facilitates escape from neutrophil extracellular traps. J Innate Immun (2010) 2:576-86. doi:10.1159/000319909

33. Burman JD, Leung E, Atkins KL, O'Seaghdha MN, Lango L, Bernado P, et al. Interaction of human complement with Sbi, a staphylococcal immunoglobulinbinding protein: indications of a novel mechanism of complement evasion by Staphylococcus aureus. J Biol Chem (2008) 283:17579-93. doi:10.1074/jbc. M800265200

34. den Reijer PM, Sandker M, Snijders SV, Tavakol M, Hendrickx AP, van Wamel WJ. Combining in vitro protein detection and in vivo antibody detection identifies potential vaccine targets against Staphylococcus aureus during osteomyelitis. Med Microbiol Immunol (2016) 206(1):11-22. doi:10.1007/s00430-016-0476-8

35. Pedersen F, Marwitz S, Holz O, Kirsten A, Bahmer T, Waschki B, et al. Neutrophil extracellular trap formation and extracellular DNA in sputum of stable COPD patients. Respir Med (2015) 109:1360-2. doi:10.1016/j. rmed.2015.08.008

36. Grabcanovic-Musija F, Obermayer A, Stoiber W, Krautgartner WD, Steinbacher P, Winterberg N, et al. Neutrophil extracellular trap (NET) formation characterises stable and exacerbated COPD and correlates with airflow limitation. Respir Res (2015) 16:59. doi:10.1186/s12931-015-0221-7

37. Dicker AJ, Crichton ML, Pumphrey EG, Cassidy AJ, Suarez-Cuartin G, Sibila O, et al. Neutrophil extracellular traps are associated with disease severity and microbiota diversity in patients with chronic obstructive pulmonary disease. J Allergy Clin Immunol (2017) 141(1):117-27. doi:10.1016/j.jaci. 2017.04.022

38. Wright TK, Gibson PG, Simpson JL, McDonald VM, Wood LG, Baines KJ. Neutrophil extracellular traps are associated with inflammation in chronic airway disease. Respirology (2016) 21:467-75. doi:10.1111/resp.12730

Conflict of Interest Statement: The authors declare that the research was conducted in the absence of any commercial or financial relationships that could be construed as a potential conflict of interest.

Copyright (C) 2018 Hoppenbrouwers, Sultan, Abraham, Lemmens-den Toom, Hansenová Maňásková, van Cappellen, Houtsmuller, van Wamel, de Maat and van Neck. This is an open-access article distributed under the terms of the Creative Commons Attribution License (CC BY). The use, distribution or reproduction in other forums is permitted, provided the original author(s) and the copyright owner are credited and that the original publication in this journal is cited, in accordance with accepted academic practice. No use, distribution or reproduction is permitted which does not comply with these terms. 